\title{
PERAN PUSTAKAWAN SEBAGAI TEMAN KARIB (TEMPAT EFEKTIF MENEMUKAN ANEKA REFERENSI ILMIAH DAN BUKU) DALAM PEMBELAJARAN
}

\author{
Mariatul Qibthiyyah \\ Universitas Lambung Mangkurat \\ Email: mariatul.qibthiyyah@ulm.ac.id
}

\begin{abstract}
The purpose of this study is to describe the effectiveness of the role of Universitas Lambung Mangkurat (ULM) librarians as TEMAN KARIB (Tempat Efektif Menemukan ANeKA Referensi, Ilmu, dan Buku) in learning. The design of this study was a mixed method with the Triangulation Design: Validating Quantitative Data Model procedure. In this model, researchers will collect quantitative data and qualitative data, then analyze each of these data. The next stage is to carry out further analysis by validating the results of quantitative analysis using qualitative results. The population in the study were all ULM students. The sample to determine the role of librarians in learning, namely 500 students. Data collection techniques are instrument validation by validators, filling out questionnaires, taking open-ended interview data to deepen the description of the effectiveness of the role of ULM librarians as TEMAN KARIB (Tempat Efektif Menemukan ANeKA Referensi, Ilmu, dan Buku) in learning. The conclusion from the results of this study is that most of the students, namely $40.466 \%$ of students agree that librarians can effectively act as TEMAN KARIB (Tempat Efektif Menemukan ANeKA Referensi, Ilmu, dan Buku) in learning. $27.84 \%$ of students strongly agree. Meanwhile, a small proportion of students, namely $7.11 \%$ and $1.34 \%$, respectively stated that they disagreed and disagreed with the statement.
\end{abstract}

Keywords : Librarians, learning, effectiveness

\begin{abstract}
Abstrak: Tujuan dari penelitian ini adalah mendeskripsikan efektivitas peran pustakawan Universitas Lambung Mangkurat (ULM) sebagai TEMAN KARIB (Tempat Efektif Menemukan ANeKA Referensi, Ilmu, dan Buku) dalam pembelajaran. Desain penelitian ini adalah mixed method dengan prosedur Triangulation Design: Validating Quantitative Data Model. Pada model ini, peneliti akan mengumpulkan data kuantitatif dan data kualitatif, kemudian menganalisis masing-masing data tersebut. Tahap selanjutnya adalah melakukan analisis lebih lanjut dengan cara memvalidasi hasil analisis kuantitatif dengan menggunakan hasil kualitatif. Populasi dalam penelitian adalah seluruh mahasiswa ULM. Sampel untuk mengetahui peran pustakawan dalam pembelajaran, yakni 500 mahasiswa. Teknik Pengumpulan Data adalah validasi instrument oleh validator, pengisian kuisioner, mengambil data wawancara open ended untuk memperdalam deskripsi tentang efektivitas peran pustakawan ULM sebagai TEMAN KARIB (Tempat Efektif Menemukan ANeKA Referensi, Ilmu
\end{abstract}


Mariatul Qibthiyyah, Peran Pustakawan Sebagai Teman Karib (Tempat ...

dan Buku) dalam pembelajaran. Teknik Analisis Data dalam kajian ini adalah sebagai berikut: 1) Validitas instrumen akan dianalisis menggunakan pemodelan Rasch; 2) Data hasil Survei akan dianalisis sesuai dengan indikator. Data akan disajikan dalam bentuk persentase dan akan di sajikan bentuk grafik dan plot yang diperoleh dengan bantuan SPSS; 3) Analisis data kualitatif dilakukan secara interaktif dan berlangsung terus menerus sampai tuntas, sehingga datanya sudah jenuh melalui langkah data reduction, coding, data display, dan verivication. Simpulan dari hasil penelitian ini adalah sebagian besar mahasiswa, yakni 40,466\% mahasiswa setuju bahwa pustakawan efektif berperan sebagai TEMAN KARIB (Tempat Efektif Menemukan ANeKA Referensi, Ilmu dan Buku) dalam pembelajaran. $27,84 \%$ mahasiswa manyataan sangat setuju. Sementara sebagian kecil mahasiswa yakni $7,11 \%$ dan $1,34 \%$ mahasiswa secara berturut-turut menyatakan bahwa mereka kurang setuju dan tidak setuju dengan pernyataan tersebut.

Kata Kunci : efektivitas; pustakawan; pembelajaran

\section{PENDAHULUAN}

Pembelajaran adalah suatu proses dimana terdapat interaksi antara peserta didik dengan pendidik dan sumber belajar dalam lingkungan belajar ${ }^{1}$. Tercapainya tujuan pembelajaran salah satunya diperoleh dari sumber belajar yang digunakan dosen dan mahasiswa. Untuk memperoleh ketercapaian tersebut, maka dalam pembelajaran harus menggunakan berbagai referensi ilmiah dan buku. Referensi ilmiah dan buku inilah yang akan membentu mahasiswa memperdalam dan memperluas pengetahuannya.

Referensi ilmiah dan buku yang digunakan untuk menunjang pembelajaran dapat ditemukan di perpustakaan. Perpustakaan adalah institusi pengelola koleksi karya tulis, karya cetak, dan/atau karya rekam secara profesional dengan sistem yang baku guna memenuhi kebutuhan pendidikan, penelitian, pelestarian, informasi, dan rekreasi para pemustaka ${ }^{2}$.

\footnotetext{
${ }^{1}$ L. Yuliati, Model-Model Pembelajaran Fisika: Teori Dan Praktek (Malang: UM, 2008).

${ }^{2}$ Perpustakaan Nasional Republik Indonesia, "Peraturan Kepala Perpustakaan Nasional Republik Indonesia Nomor 11 Tahun 2015 Tentang Petunjuk Teknis Jabatan Fungsional Pustakawan Dan Angka Kreditnya" (2015); Lulu Andarini Aziz, "Upaya Perpustakaan Dalam Mengurangi Plagiarisme Pada Karya Ilmiah Mahasiswa (Studi Kasus Di Upt Perpustakaan Unika Soegijapranata)," Jurnal Ilmu Perpustakaan 4, no. 3 (2015): 131-40.
} 


\section{Pustakaloka: Zurnal Kajian 2nformasi dan Perpustakaan}

Volume 12 No. 2, Desember 2020

Perpustakaan saat ini semakin dituntut untuk meningkatkan layanan ${ }^{3}$. Jasa dan layanan di perpustakaan sangat bergantung pada tenaga profesional yang ada di perpustakaan tersebut. Perpustakaan memiliki para profesional dibidang perpustakaan yang disebut dengan pustakawan.

Pustakawan memiliki latar belakang pendidikan perpustakaan, ada tenaga teknis perpustakaan yang paham secara teknis mengelolah informasi, serta yang paling utama adalah perpustakaan memiliki informasi yang kredibel dimana informasi tersebut dapat dijual sebagai produk jasa kepada masyarakat ${ }^{4}$. Apabila pelayanan yang diterima atau dirasakan sesuai dengan apa yang diharapkan pengguna perpustakaan, maka kualitas pelayanan direspon baik dan memuaskan ${ }^{5}$. Pesatnya kemajuan ilmu pengetahuan dan teknologi informasi yang terus berkembang memerlukan pustakawan yang kreatif dan inovatif, serta terus menerus membuka diri. Pustakawan yang kreatif dan inovatif mampu mendayagunakan modal intelektual dan keterampilan dalam melaksanakan tugas ${ }^{6}$.

Kata efektif berarti berhasil, berperan, atau atau berpengaruh. Dengan demikian, pustakawan dikatakan efektif dalam perannya jika pemustaka berhasil menemukan dan memanfaatkan aneka referensi ilmiah dan buku. Mahasiswa memerlukan jasa dan layanan dari pustakawan yang efektif untuk proses perkuliahan. Efektivitas peran pustakawan dalam membantu pemustaka untuk menemukan aneka referensi ilmiah dan buku sangat menentukan kualitas dari Perpustakaan tersebut. Oleh karena itu, perlu di pelajari lebih lanjut bagaimana efektivitas peran pustakawan dalam membantu pemustaka untuk menemukan aneka referensi ilmiah. Tujuan dari penelitian ini adalah mendeskripsikan efektivitas peran pustakawan ULM sebagai TEMAN KARIB (Tempat Efektif Menemukan ANeKA Referensi, Ilmu dan Buku) dalam pembelajaran.

3 C C Asmad and Taufiq Mathar, "Peran Pustakawan Dalam Meningkatkan Kinerja Perpustakaan," Khazanah Al-Hikmah 3, no. 2 (2015).

4 Dian Kristyanto, "Reference Agent: Mengoptimalkan Pustakawan Dalam Menghidupkan Kembali Layanan Referensi," Pustakaloka 7, no. 1 (2015): 1-14.

5 Zurni Zahara Samosir, "Pengaruh Kualitas Pelayanan Terhadap Kepuasan Mahasiswa Menggunakan Perpustakaan USU Departemen Studi," Pustaha: Jurnal Studi Perpustakaan Dan Informasi 1, no. 1 (2005): 28-36.

${ }^{6}$ Gatot Subrata, "Upaya Pengembangan Kinerja Pustakawan Perguruan Tinggi Di Era Globalisasi Informasi,” Jurnal Pustakawan Perpustakaan UM 1, no. 1 (2009): 1-12. 
Mariatul Qibthiyyah, Peran Pustakawan Sebagai Teman Karib (Tempat ...

\section{METODE PENELITIAN}

Desain penelitian ini adalah mixed method dengan prosedur Triangulation Design: Validating Quantitative Data Model. Pada model ini, peneliti akan mengumpulkan data kuantitatif dan data kualitatif, kemudian menganalisis masing-masing data tersebut. Tahap selanjutnya adalah melakukan analisis lebih lanjut dengan cara memvalidasi hasil analisis kuantitatif dengan menggunakan hasil kualitatif.

Populasi dalam penelitian adalah seluruh mahasiswa ULM. Sampel untuk mengetahui peran pustakawan dalam pembelajaran, yakni 500 mahasiswa. Data kualitatif diambil dari 10 mahasiswa yang diambil secara acak (random sampling) dari sampel. Pengumpulan data dalam penelitian ini dilakukan sebagai berikut (1) Validasi instrumen penelitian oleh para validator untuk menghasilkan kuisioner dan pedoman wawancara yang valid; (2) Pengisian kuisioner untuk menjawab semua rumusan masalah; (3) Mengambil data wawancara open ended untuk memperdalam deskripsi tentang peran pustakawan sebagai TEMAN KARIB (Tempat Efektif Menemukan ANeKA Referensi, Ilmu dan Buku) dalam pembelajaran.

Data hasil Survei akan dianalisis sesuai dengan indikator dari efektivitas peran pustakawan ULM terhadap pembelajaran di ULM. Data akan disajikan dalam bentuk persentase dan akan di sajikan bentuk grafik dan plot.

\section{KAJIAN TEORI}

Salah satu tri dharma perguruan tinggi adalah pendidikan. Perguruan tinggi idaman harusnya mempunyai sistem pendidikan dan pengajaran yang up to date. Tercapainya tujuan pembelajaran salah satunya diperoleh dari sumber belajar yang digunakan dosen dan mahasiswa. Untuk memperoleh ketercapaian tersebut, maka dalam pembelajaran harus menggunakan berbagai referensi ilmiah dan buku. Referensi ilmiah dan buku inilah yang akan membentu mahasiswa memperdalam dan memperluas pengetahuannya.

Pesatnya kemajuan ilmu pengetahuan dan teknologi informasi yang terus berkembang memerlukan pustakawan yang kreatif dan inovatif, serta terus 
menerus membuka diri. Pustakawan yang kreatif dan inovatif mampu mendayagunakan modal intelektual dan keterampilan dalam melaksanakan tugas. ${ }^{7}$ Pustakawan yang mampu menhadapi ini akan menjadi TEMAN KARIB (Tempat Efektif Menemukan ANeKA Referensi, Ilmu dan Buku).

Efektif berarti memiliki berhasil, berperan, atau atau berpengaruh. Dengan demikian, pustakawan dikatakan efektif jika pemustaka berhasil menemukan dan memanfaatkan aneka referensi ilmiah dan buku. Dosen dan mahasiswa memerlukan jasa dan layanan dari pustakawan yang efektif untuk proses perkuliahan dan penelitian. Efektivitas peran pustakawan dalam membantu pemustaka untuk menemukan aneka referensi ilmiah dan buku sangat menentukan kualitas dari Perpustakaan tersebut.

\section{HASIL PENELITIAN DAN PEMBAHASAN}

Dalam menafsirkan Undang-undang Nomor 43 tahun 2007 terdapat beberapa hal yang harus dimiliki oleh pustakawan perguruan tinggi pada era global antara lain : (1) Memiliki Pendidikan dan Ketrampilan Tentang Kepustakawanan, (2) Memiliki Ketrampilan Pemanfaatan Teknologi Informasi, (3) Memiliki Ketrampilan Bahasa, (4) Mengetahui Kebutuhan Pemustaka, dan (5) Sense of Media. Lima komponen ini lah yang menjadi indikator untuk mengetahui efektivitas peran pustakawan sebagai TEMAN KARIB (Tempat Efektif Menemukan ANeKA Referensi, Ilmu, dan Buku) dalam pembelajaran.

Data hasil Survei dianalisis sesuai dengan indikator dari efektivitas peran pustakawan ULM terhadap pembelajaran di ULM.

\footnotetext{
${ }^{7}$ Subrata.
} 
1. Memiliki Pendidikan dan Keterampilan Tentang Kepustakawanan,

\section{Gambar I}

Tanggapan mahasiswa tentang pustakawan yang memiliki pendidikan dan keterampilan

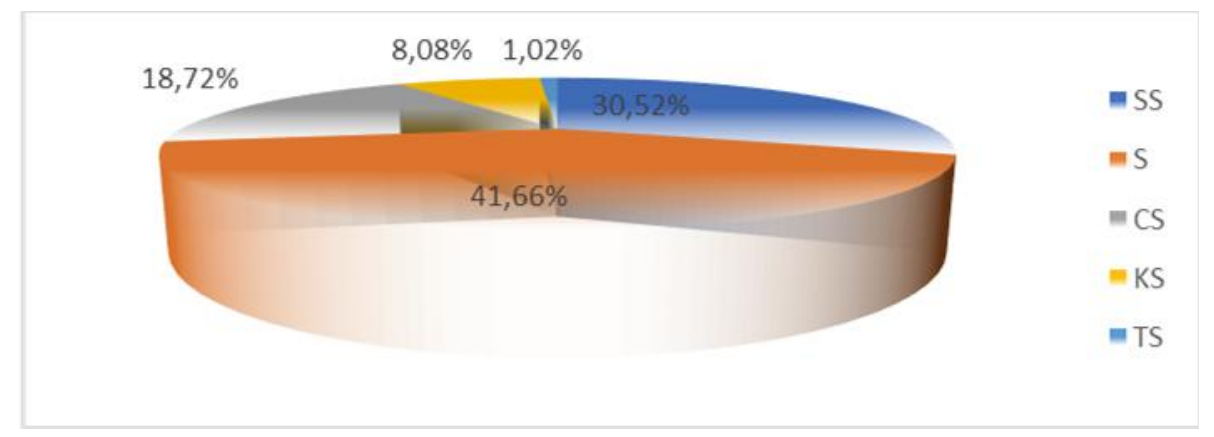

Pada poin ini dilihat berapa persentase mahasiswa yang menyetujui bahwa pustakawan memiliki pendidikan dan keterampilan tentang kepustakawanan. Ada pun butir pertanyaan yang diberikan adalah Pustakawan memberikan jasa pelayanan kepada mahasiswa yang membutuhkan buku dan karya ilmiah yang digunakan dalam pembelajaran; Pustakawan bersikap ramah terhadap mahasiswa yang mencari buku dan karya ilmiah yang digunakan dalam pembelajaran; Pustakawan memberikan bantuan ketika mahasiswa mengalami kesulitan dalam mencari buku dan karya ilmiah yang digunakan dalam pembelajaran; Pustakawan mampu memberikan informasi tentang posisi/status buku dan karya ilmiah yang dicari mahasiswa.

Berdasarkan Gambar 1, mahasiswa sebagian besar, yakni 41,66\% setuju bahwa pustakawan memiliki pendidikan dan keterampilan tentang kepustakawanan yang membantu mahasiswa dalam menemukan aneka buku dan referensi untuk pembelajaran. 30,52\% sangat setuju bahwa pustakawan memiliki pendidikan dan keterampilan tentang kepustakawanan yang membantu mahasiswa dalam menemukan aneka buku dan referensi untuk pembelajaran. $18,72 \%$ cukup setuju bahwa pustakawan memiliki pendidikan dan keterampilan tentang kepustakawanan yang membantu mahasiswa dalam menemukan aneka buku dan referensi untuk pembelajaran. 8,08\% kurang setuju bahwa pustakawan memiliki pendidikan dan keterampilan tentang 
kepustakawanan yang membantu mahasiswa dalam menemukan aneka buku dan referensi untuk pembelajaran. 1,02\% tidak setuju bahwa pustakawan memiliki pendidikan dan keterampilan tentang kepustakawanan yang membantu mahasiswa dalam menemukan aneka buku dan referensi untuk pembelajaran.

2. Memiliki Ketrampilan Pemanfaatan Teknologi Informasi,

Pada poin ini dilihat berapa persentase mahasiswa yang menyetujui bahwa pustakawan memiliki keterampilan pemanfaatan teknologi informasi. Ada pun butir pertanyaan yang diberikan adalah Pustakawan memiliki keterampilan dalam mengoperasikan komputer yang tersedia di perpustakaan; Pustakawan membantu mahasiswa dalam menggunakan katalog online untuk menemukan buku dan karya ilmiah yang digunakan dalam pembelajaran; Pustakawan memberikan layanan sirkulasi sesuai dengan teknologi yang disediakan.

\section{Gambar II \\ Tanggapan mahasiswa tentang pustakawan yang memiliki keterampilan pemanfaatan teknologi informasi}

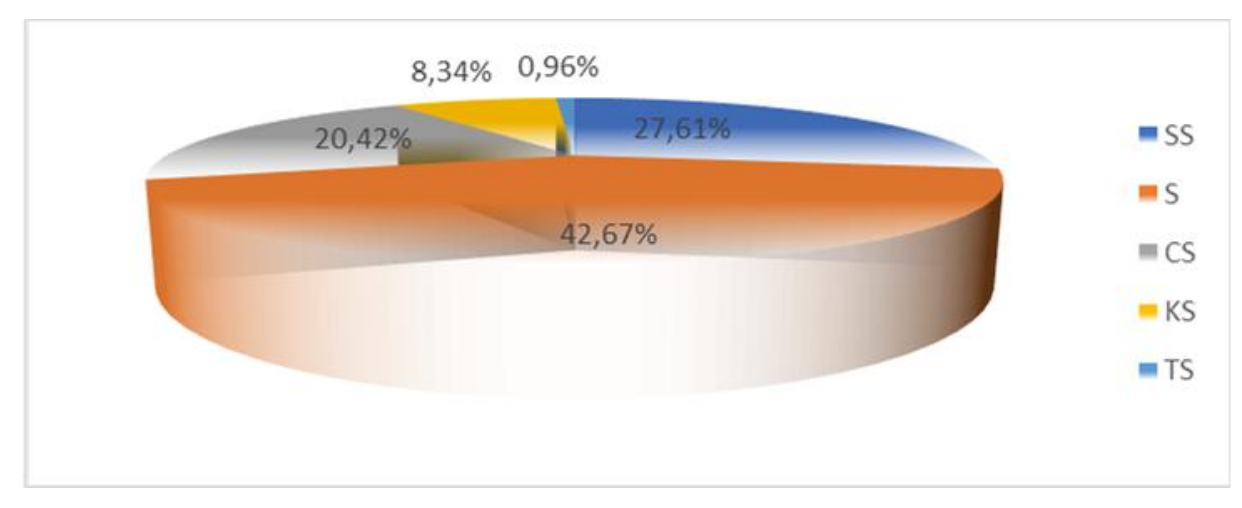

Berdasarkan Gambar 2, mahasiswa sebagian besar, yakni 42,67\% setuju bahwa pustakawan yang memiliki keterampilan pemanfaatan teknologi informasi yang membantu mahasiswa dalam menemukan aneka buku dan referensi untuk pembelajaran. 27,61\% sangat setuju bahwa pustakawan yang memiliki keterampilan pemanfaatan teknologi informasi yang membantu mahasiswa dalam menemukan aneka buku dan referensi untuk pembelajaran. 
Mariatul Qibthiyyah, Peran Pustakawan Sebagai Teman Karib (Tempat ...

20,42\% cukup setuju bahwa pustakawan yang memiliki keterampilan pemanfaatan teknologi informasi yang membantu mahasiswa dalam menemukan aneka buku dan referensi untuk pembelajaran. 8,34\% kurang setuju bahwa pustakawan yang memiliki keterampilan pemanfaatan teknologi informasi yang membantu mahasiswa dalam menemukan aneka buku dan referensi untuk pembelajaran. $0,96 \%$ tidak setuju bahwa pustakawan yang memiliki keterampilan pemanfaatan teknologi informasi yang membantu mahasiswa dalam menemukan aneka buku dan referensi untuk pembelajaran.

3. Memiliki Keterampilan Bahasa

Pada poin ini dilihat berapa persentase mahasiswa yang menyetujui bahwa pustakawan memiliki keterampilan berbahasa. Ada pun butir pertanyaan yang diberikan adalah Pustakawan memiliki keterampilan berkomunikasi yang baik; Pustakawan bersikap sopan dan ramah kepada pengunjung

\section{Gambar III}

Tanggapan mahasiswa tentang pustakawan yang memiliki keterampilan berbahasa

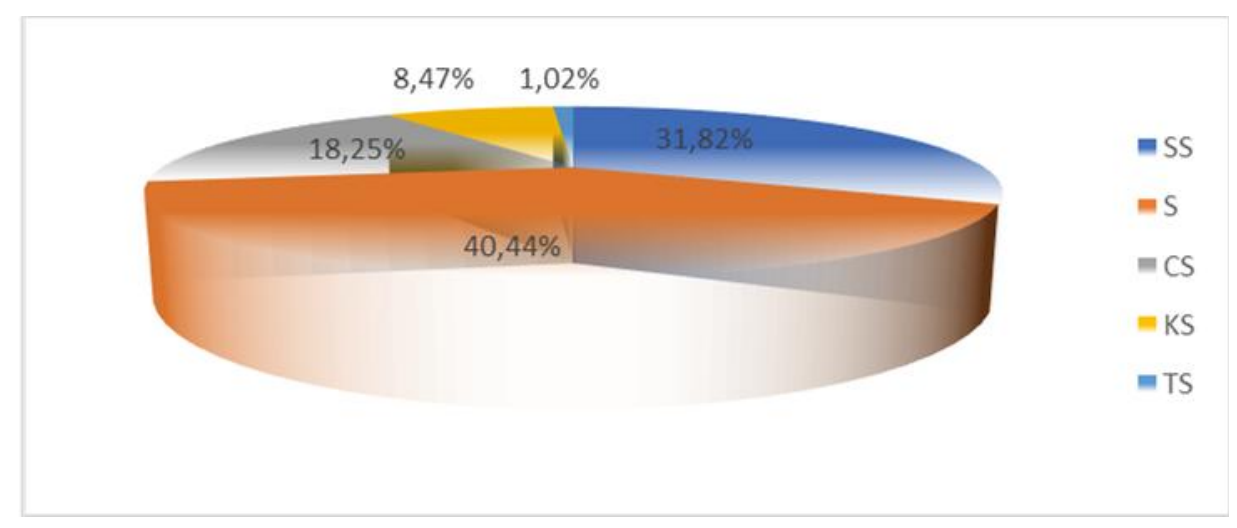

Berdasarkan Gambar 3, mahasiswa sebagian besar, yakni 40,44\% setuju bahwa pustakawan yang memiliki keterampilan berbahasa yang membantu mahasiswa dalam menemukan aneka buku dan referensi untuk pembelajaran. $31,82 \%$ sangat setuju bahwa pustakawan yang memiliki keterampilan berbahasa yang membantu mahasiswa dalam menemukan aneka buku dan referensi untuk pembelajaran. 18,25\% cukup setuju bahwa pustakawan yang memiliki keterampilan berbahasa yang membantu 
mahasiswa dalam menemukan aneka buku dan referensi untuk pembelajaran. $8,47 \%$ kurang setuju bahwa pustakawan yang memiliki keterampilan berbahasa yang membantu mahasiswa dalam menemukan aneka buku dan referensi untuk pembelajaran. 1,02 \% tidak setuju bahwa pustakawan yang memiliki keterampilan berbahasa yang membantu mahasiswa dalam menemukan aneka buku dan referensi untuk pembelajaran.

4. Mengetahui Kebutuhan Pemustaka,

\section{Gambar IV}

Tanggapan mahasiswa tentang pustakawan yang mengetahui kebutuhan pemustaka

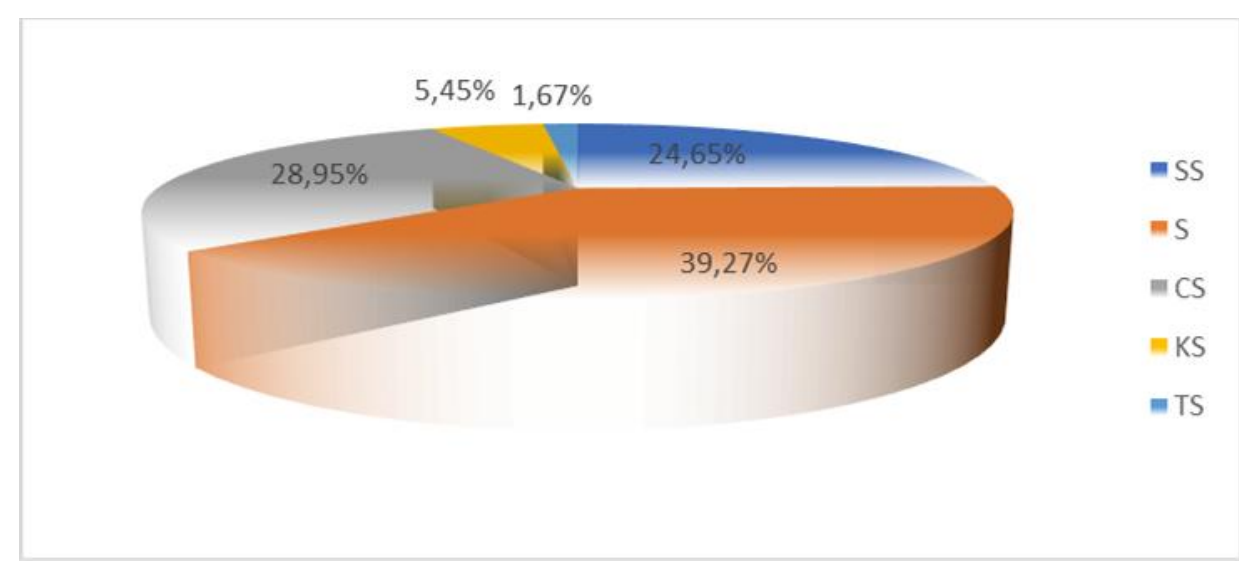

Pada poin ini dilihat berapa persentase mahasiswa yang menyetujui bahwa pustakawan mengetahui kebutuhan pemustaka. Ada pun butir pertanyaan yang diberikan adalah Pustakawan menampung saran/masukan untuk pengadaan buku dan karya ilmiah yang dicari oleh mahasiswa namun tidak tersedia di perpustakaan; Pustakawan mencari informasi buku dan karya ilmiah apa saja yang dibutuhkan mahasiswa dalam pembelajaran; Pustakawan mengadakan survei kebutuhan dan kelengkapan buku dan karya ilmiah yang digunakan dalam pembelajaran; Pustakawan memberikan kelancaran dalam menemukan buku dan karya ilmiah yang digunakan dalam pembelajaran.

Berdasarkan Gambar 4 mahasiswa sebagian besar, yakni 39,27\% setuju bahwa pustakawan yang mengetahui kebutuhan pemustaka yang membantu mahasiswa dalam menemukan aneka buku dan referensi untuk pembelajaran. $24,65 \%$ sangat setuju bahwa pustakawan yang mengetahui 
Mariatul Qibthiyyah, Peran Pustakawan Sebagai Teman Karib (Tempat ...

kebutuhan pemustaka yang membantu mahasiswa dalam menemukan aneka buku dan referensi untuk pembelajaran. 28,95\% cukup setuju bahwa pustakawan yang mengetahui kebutuhan pemustaka yang membantu mahasiswa dalam menemukan aneka buku dan referensi untuk pembelajaran. $5,45 \%$ kurang setuju bahwa pustakawan yang mengetahui kebutuhan pemustaka yang membantu mahasiswa dalam menemukan aneka buku dan referensi untuk pembelajaran. 1,67\% tidak setuju bahwa pustakawan yang mengetahui kebutuhan pemustaka yang membantu mahasiswa dalam menemukan aneka buku dan referensi untuk pembelajaran.

5. Sense of Media.

\section{Gambar V}

\section{Tanggapan mahasiswa tentang pustakawan yang memiliki sense of media}

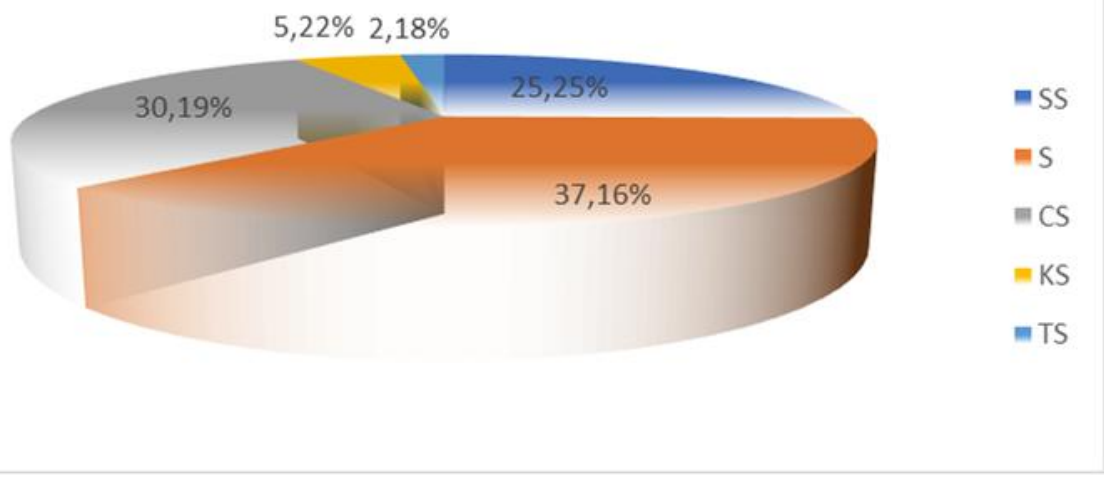

Berdasarkan Gambar 5, mahasiswa sebagian besar, yakni 37,16\% setuju bahwa pustakawan yang memiliki sense of media yang membantu mahasiswa dalam menemukan aneka buku dan referensi untuk pembelajaran. $25,25 \%$ sangat setuju bahwa pustakawan yang memiliki sense of media yang membantu mahasiswa dalam menemukan aneka buku dan referensi untuk pembelajaran. $30,19 \%$ cukup setuju bahwa pustakawan yang memiliki sense of media yang membantu mahasiswa dalam menemukan aneka buku dan referensi untuk pembelajaran. 5,22\% kurang setuju bahwa pustakawan yang memiliki sense of media yang membantu mahasiswa dalam menemukan aneka buku dan referensi untuk pembelajaran. 2,18\% tidak setuju bahwa 
pustakawan yang memiliki sense of media yang membantu mahasiswa dalam menemukan aneka buku dan referensi untuk pembelajaran.

Pada poin ini dilihat berapa persentase mahasiswa yang menyetujui bahwa pustakawan memiliki sense of media. Ada pun butir pertanyaan yang diberikan adalah Pustakawan peka dan mengetahui terhadap adanya mediamedia terbaru seperti ebook, jurnal online, dan media lainnya yang berguna sebagai referensi dalam pembelajaran; Pustakawan mengetahui dan memberikan informasi tentang media-media cetak diperpustakaan dan informasi apa yang ada di dalamnya

\section{Gambar VI}

Tanggapan mahasiswa tentang efektivitas peran pustakawan sebagai TEMAN KARIB

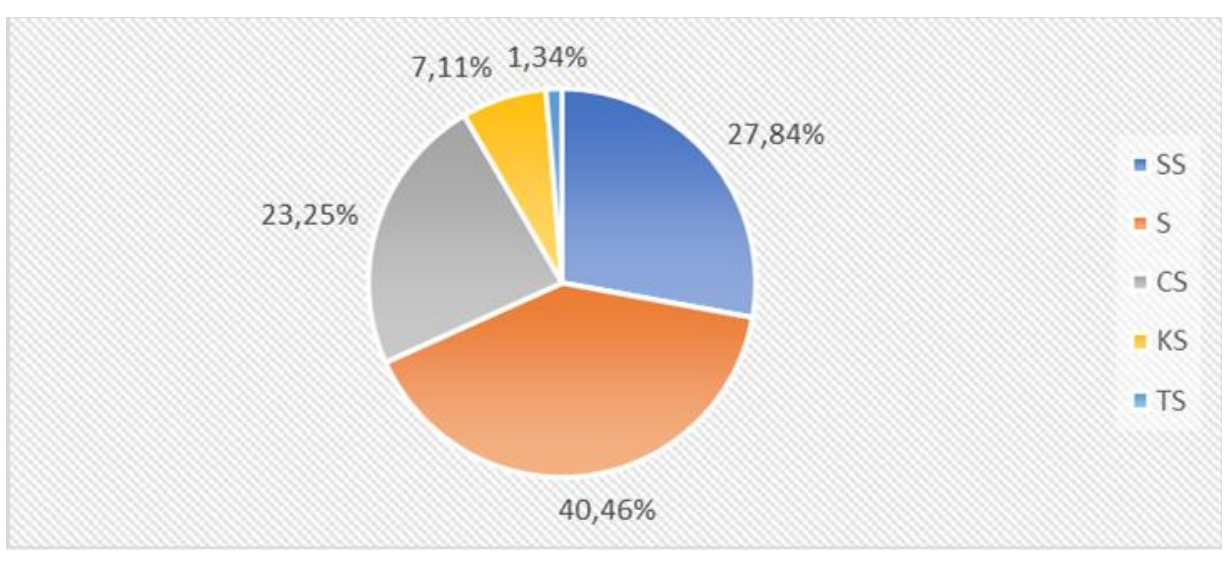

Secara keseluruhan, efektivitas Peran pustakawan sebagai TEMAN KARIB (Tempat Efektif Menemukan ANeKA Referensi, Ilmu, dan Buku) dalam pembelajaran dapat dilihat pada Gambar 4.17. Gambar 4.17 menunjukkan bahwa sebagian besar mahasiswa, yakni 40,466\% mahasiswa setuju bahwa pustakawan efektif berperan sebagai TEMAN KARIB (Tempat Efektif Menemukan ANeKA Referensi, Ilmu, dan Buku) dalam pembelajaran. 27,84\% mahasiswa manyataan sangat setuju. Sementara sebagian kecil mahasiswa yakni 7,11\% dan 1,34\% mahasiswa secara berturutturut menyatakan bahwa mereka kurang setuju dan tidak setuju dengan pernyataan tersebut. 
Mariatul Qibthiyyah, Peran Pustakawan Sebagai Teman Karib (Tempat ...

\section{PENUTUP}

\section{Simpulan}

Simpulan dari hasil penelitian ini adalah sebagian besar mahasiswa, yakni 40,466\% mahasiswa setuju bahwa pustakawan efektif berperan sebagai TEMAN KARIB (Tempat Efektif Menemukan ANeKA Referensi, Ilmu, dan Buku) dalam pembelajaran. 27,84\% mahasiswa manyataan sangat setuju. Sementara sebagian kecil mahasiswa yakni $7,11 \%$ dan $1,34 \%$ mahasiswa secara berturut-turut menyatakan bahwa mereka kurang setuju dan tidak setuju dengan pernyataan tersebut.

\section{Saran}

Berdasarkan hasil penelitian, pustakawan diharapkan meningkatkan segala kompetensi dan keterampilannya yang berkaitan dengan kepustakawanan sehingga membantu mahasiswa dalam memperlancar proses pembelajaran.

\section{DAFTAR RUJUKAN}

Asmad, C C, and Taufiq Mathar. "Peran Pustakawan Dalam Meningkatkan Kinerja Perpustakaan.” Khazanah Al-Hikmah 3, no. 2 (2015).

Aziz, Lulu Andarini. "Upaya Perpustakaan Dalam Mengurangi Plagiarisme Pada Karya Ilmiah Mahasiswa (Studi Kasus Di Upt Perpustakaan Unika Soegijapranata)." Jurnal Ilmu Perpustakaan 4, no. 3 (2015): 131-40.

Kristyanto, Dian. "Reference Agent: Mengoptimalkan Pustakawan Dalam Menghidupkan Kembali Layanan Referensi." Pustakaloka 7, no. 1 (2015): $1-14$.

Perpustakaan Nasional Republik Indonesia. Peraturan Kepala Perpustakaan Nasional Republik Indonesia Nomor 11 Tahun 2015 Tentang Petunjuk Teknis Jabatan Fungsional Pustakawan Dan Angka Kreditnya (2015).

Samosir, Zurni Zahara. "Pengaruh Kualitas Pelayanan Terhadap Kepuasan Mahasiswa Menggunakan Perpustakaan USU Departemen Studi." Pustaha: Jurnal Studi Perpustakaan Dan Informasi 1, no. 1 (2005): 2836.

Subrata, Gatot. "Upaya Pengembangan Kinerja Pustakawan Perguruan Tinggi Di Era Globalisasi Informasi.” Jurnal Pustakawan Perpustakaan UM 1, no. 1 (2009): 1-12.

Yuliati, L. Model-Model Pembelajaran Fisika: Teori Dan Praktek. Malang: UM, 2008. 